\title{
Magnetite-Arginine Nanoparticles as a Multifunctional Biomedical Tool
}

\author{
Victoria E. Reichel 1,2, Jasmin Matuszak ${ }^{3,4}$, Klaas Bente ${ }^{1,5}$, Tobias Heil ${ }^{1}$, \\ Alexander Kraupner ${ }^{6}\left(\mathbb{D}\right.$, Silvio Dutz ${ }^{7}$ (D), Iwona Cicha ${ }^{3}$ and Damien Faivre ${ }^{1,8, *(D)}$ \\ 1 Max Planck Institute of Colloids and Interfaces, Department of Biomaterials, Am Mühlenberg 1, \\ 14476 Potsdam, Germany; victoria.reichel@univ-paris-diderot.fr (V.E.R.); klaas.bente@bam.de (K.B.); \\ tobias.heil@mpikg.mpg.de (T.H.) \\ 2 Laboratoire “Matière et Systèmes Complexes" (MSC), UMR 7057 CNRS, Université Paris 7 Diderot, \\ 75205 Paris CEDEX 13, France \\ 3 Section of Experimental Oncoclogy and Nanomedicine (SEON), ENT Department, \\ University Hospital Erlangen, Friedrich-Alexander-Universität Erlangen-Nürnberg, Glückstraße 10a, \\ 91054 Erlangen, Germany; jasmin.matuszak@charite.de (J.M.); iwona.cicha@uk-erlangen.de (I.C.) \\ 4 Department of Anesthesiology, Kurume University Hospital, Cognitive and MolecularResearch Institute \\ of Brain Diseases, Kurume University, 65-1, Asahimachi, Kurume 830-0011, Japan \\ 5 Bundesanstalt für Materialforschung und -prüfung, Unter den Eichen 87, 12205 Berlin, Germany \\ 6 nanoPET Pharma GmbH, Luisencarrée Robert-Koch-Platz 4, 10115 Berlin, Germany; \\ alexander.kraupner@nanopet.de \\ 7 Institute of Biomedical Engineering and Informatics, Technische Universität Ilmenau, PF 100565, \\ 98684 Ilmenau, Germany; Silvio.Dutz@tu-ilmenau.de \\ 8 Aix-Marseille Université, CEA, CNRS, BIAM, 13108 Saint Paul lez Durance, France \\ * Correspondence: damien.faivre@cea.fr
}

Received: 5 August 2020; Accepted: 2 October 2020; Published: 13 October 2020

\begin{abstract}
Iron oxide nanoparticles are a promising platform for biomedical applications, both in terms of diagnostics and therapeutics. In addition, arginine-rich polypeptides are known to penetrate across cell membranes. Here, we thus introduce a system based on magnetite nanoparticles and the polypeptide poly-L-arginine (poly $\mathrm{R}_{-} \mathrm{Fe}_{3} \mathrm{O}_{4}$ ). We show that the hybrid nanoparticles exhibit a low cytotoxicity that is comparable to Resovist ${ }^{\circledR}$, a commercially available drug. PolyR- $-\mathrm{Fe}_{3} \mathrm{O}_{4}$ particles perform very well in diagnostic applications, such as magnetic particle imaging (1.7 and 1.35 higher signal respectively for the 3rd and 11th harmonic when compared to Resovist ${ }^{\circledR}$ ), or as contrast agents for magnetic resonance imaging (R2/R1 ratio of 17 as compared to 11 at $0.94 \mathrm{~T}$ for Resovist $\left.{ }^{\circledR}\right)$. Moreover, these novel particles can also be used for therapeutic purposes such as hyperthermia, achieving a specific heating power ratio of $208 \mathrm{~W} / \mathrm{g}$ as compared to $83 \mathrm{~W} / \mathrm{g}$ for Feride ${ }^{\circledR}$, another commercially available product. Therefore, we envision such materials to play a role in the future theranostic applications, where the arginine ability to deliver cargo into the cell can be coupled to the magnetite imaging properties and cancer fighting activity.
\end{abstract}

Keywords: iron oxide; nanoparticle; theranostics; MRI; hyperthermia

\section{Introduction}

Magnetic nanoparticles, in particular iron oxide particles, hold great a promise for environmental, biomedical and clinical applications [1]. They are employed for a variety of in vitro and in vivo applications, including drug delivery, gene delivery, hyperthermia and can be used in magnetic resonance imaging (MRI) as contrast agents. In recent years, various different systems based on magnetic iron oxide nanoparticles and their coatings have been introduced for potential usage in diagnostics and therapeutics [2-8]. 
Key characteristics for these applications are the particle dimensions, which directly govern the magnetic properties of the crystal, but also the colloidal stability that affects the aggregation. For example, the heating efficiency in magnetic particle hyperthermia is governed by the mechanism of magnetic energy dissipation for stable single domain nanoparticles (Brownian and Neel relaxation) [9], which correspond to size between about 10 and $100 \mathrm{~nm}$. According to these desired properties, a variety of synthetic magnetic single domain nanoparticles have been designed for magnetic hyperthermia in recent years. To name a few, chitosan oligosaccharide-stabilized ferrimagnetic iron oxide nanocubes [10], iron oxide nanoparticles coated with D-mannitol [11], self-assembled nanostructured cubosomes [12], and magnetic nanoparticles with covalently bound folic acid linked to a copolymer [13].

In MRI, the optimal size is slightly different as been theoretically described [14]. Despite slight divergences in dimension, various systems produced for magnetic hyperthermia can also be used as MRI contrast agents [15]. This list includes mono- and multi-core iron oxide nanoparticles [12] and nearly mono-disperse iron oxide magnetic nanocubes [16]. It was shown recently, that multi-core iron oxide nanoparticles are promising candidates for medical applications, such as hyperthermia, MRI and MPI, which is confirmed by a few animal studies up to now [17]. Larger ferrimagnetic nanoparticles with remanent particle magnetization can lead to particle agglomerates, reaching a critical size similar to that of the red blood cell, around $6 \mu \mathrm{m}$. This leads to a high risk of occluding blood vessels of a patient and cause dangerous side effects, even when those particles are coated and even in the absence of an external magnetic field. Alternatively, multi-core nanoparticles display a very weak remanence in a zero field and blood clotting is prevented [18].

In general, the above-mentioned nanoparticles are synthesized by high-temperature processes, and/or complex chemical procedures including several steps and non-environmentally friendly conditions. Biomimetic syntheses have recently advanced as a promising approach towards high-value magnetite particles and assemblies formed under green conditions [19]. Examples are the use of proteins from magnetotactic bacteria [19-23], or of synthetic peptides [24,25] as additive of reaction. Along these lines, we have recently designed a synthetic process towards highly monodisperse and colloidally stable magnetite nanoparticles based on a one-pot synthesis at low temperature by the addition of a polypeptide in a modified co-precipitation assay [26]. The obtained particles have dimension similar to that of magnetosomes, particles formed by magnetotactic bacteria [27], the later with high potential for hyperthermia [2,28,29], as well as contrast agent for MRI [14,30], and for MPI [31]. Due to these similarities and supported by recent work on the use of (poly)arginine in medical application in general [32], and as cell penetrating peptide in particular [33], we decided to investigate the biomedical potential of our magnetite-poly-arginine system. Here, we show that indeed, these particles are biocompatible and exhibit effective properties in terms of hyperthermia, MRI and MPI, while being easy to produce.

\section{Materials and Methods}

\subsection{Nanoparticle Synthesis and Characterization}

\subsubsection{Synthesis of polyR- $\mathrm{Fe}_{3} \mathrm{O}_{4}$ Nanoparticles}

Magnetite nanoparticles were synthesized by co-precipitation in an aqueous solution as previously described [34]. Briefly, ferrous and ferric iron chloride salts form magnetite by hydrolysis with sodium hydroxide within an alkaline milieu. A computer-controlled titration device which consists of a titration unit (Metrohm Titrino 888) equipped with a $5 \mathrm{~mL}$ cylinder, a dosing unit (Metrohm Dosimat 805) containing a $1 \mathrm{~mL}$ unit and a Biotrode $\mathrm{pH}$ electrode was used (Metrohm AG, Filderstadt, Germany). A $50 \mathrm{~mL}$ reaction vessel with a thermostat was used and the temperature was kept constant at $25^{\circ} \mathrm{C}$. In addition, the reactor was kept under a controlled nitrogen atmosphere and all solutions were deoxygenated with nitrogen. The reaction vessel was filled with $10 \mathrm{~mL}$ of $\mathrm{H}_{2} \mathrm{O}$ MilliQ to which poly-L-arginine (15,000 MW-70,000 MW) was added until the final concentration of $0.1 \mathrm{mg} \mathrm{mL}^{-1}$ was reached. Iron (II) chloride tetrahydrate and iron (III) chloride hexahydrate 
were used in a stoichiometric ratio of magnetite $\left(\mathrm{Fe}^{\mathrm{II}} / \mathrm{Fe}^{\mathrm{III}}=\frac{1}{2}\right)$ to prepare a $0.1 \mathrm{M}$ iron solution. A $0.1 \mathrm{M} \mathrm{NaOH}$ solution was used for titration. The reaction was started by addition of the iron solution $\left(1 \mu \mathrm{L} \mathrm{min}{ }^{-1}\right)$ to the reaction vessel containing the poly-L-arginine solution under continuous stirring using a mechanical stirrer. The $\mathrm{pH}$ value was kept under permanent control at $\mathrm{pH} 11$ using the $\mathrm{NaOH}$ titration unit and a $\mathrm{pH}$ electrode.

\subsubsection{Transmission Electron Microscopy}

Scanning transmission electron microscopy (STEM) images were acquired with a double Cs-corrected ARM200F instrument (JEOL, Tokyo, Japan) set to an acceleration voltage of $200 \mathrm{kV}$. The samples were prepared as follows: $10 \mu \mathrm{L}$ of the sample suspensions were dropped on a Parafilm slice. A carbon coated copper grid was placed on the drop with the carbon side facing towards the fluid for $15 \mathrm{~min}$. The liquid phase was then removed afterwards using a precision tissue paper and the grids were washed twice by placing them on a drop of $\mathrm{H}_{2} \mathrm{O}$ MilliQ for $5 \mathrm{~min}$.

\subsubsection{Dynamic Light Scattering and Zeta Potential}

Dynamic light scattering (DLS) was used to characterize the particles in terms of their size and colloidal stability. The mean intensity-weighted hydrodynamic diameter $\mathrm{d}_{\mathrm{h}}$ was determined using a NICOMP Submicron Particle Sizer Model 370 (Particle Sizing Systems, Santa Barbara, CA, USA). $200 \mu \mathrm{L}$ of $0.5 \mathrm{mM}(\mathrm{Fe})$ aqueous sample dispersion was filled in a $5 \mathrm{~mm}$ glass tube and measured for $5 \mathrm{~min}$.

\subsection{Biocompatibility}

\subsubsection{Real-Time Cell Analysis}

Real-time cell analysis experiments were performed using a xCELLigence system (RTCA DP Analyzer, Roche Diagnostics, Mannheim, Germany). Human umbilical vein endothelial cells (HUVECs) were isolated from freshly collected umbilical cords provided by the Department of Gynecology at the University Hospital Erlangen. HUVECs at passage 1 were used for all experiments. The experiments were performed in 16-well E-plates (ACEA Bioscience, San Diego, CA, USA), in which the impedance was measured with the help of microelectrodes localized at the bottom of the wells. Background measurements were performed while adding $100 \mu \mathrm{L}$ of sterile endothelial cell growth medium within the wells. Afterwards, $50 \mu \mathrm{L}$ of the previously prepared cell suspension at a concentration of $1 \times 10^{3}$ was added by replacing $50 \mu \mathrm{L}$ of media from each well. The impedance was monitored using the $x$ CELLigence system. The effects of polyR- $\mathrm{Fe}_{3} \mathrm{O}_{4}$ nanoparticles on HUVEC viability were monitored as follows: After the first $24 \mathrm{~h}$ of cell growth, $100 \mu \mathrm{L}$ of additional media, containing polyR-Fe $\mathrm{O}_{4}$ particles or Resovist ${ }^{\circledR}$, or without particles were added. Final nanoparticle concentrations of $0,12.5,25,50,100,200$ and $400 \mu \mathrm{g} \mathrm{ml}^{-1}$ were chosen. The cell growth was monitored every $10 \mathrm{~min}$ for $96 \mathrm{~h}$ on hexaplicate samples [35].

\subsubsection{Live-Cell Microscopy}

HUVECs were seeded at a concentration of $1 \times 10^{3}$ cells per well in 96-well plates in $100 \mu \mathrm{L}$ medium each. At $24 \mathrm{~h}$ after seeding, $100 \mu \mathrm{L}$ of medium with or without Resovist ${ }^{\circledR}$ or polyR-Fe $\mathrm{O}_{4}$ particles were added to the wells to the final concentrations of $0,12.5,25,50,100,200$ and $400 \mu \mathrm{g} \mathrm{mL}{ }^{-1}$. The cell growth was monitored with a live cell-imager (IncuCyte FLR microscope system, Essen Bioscience, Ann Arbor, MI, USA) for $96 \mathrm{~h}$ hours. The experiments were performed in hexaplicates [35].

\subsubsection{Flow Experiments with Bifurcation Model}

Bifurcation flow-through cell culture slides (y-shaped $\mu$-slides, Ibidi ${ }^{\circledR}$, Munich, Germany) were used for direct microscopic studies. Numerical flow simulations identified distinct regions of 
shear stress: The laminar shear stress region (10.2-10.8 dyne $\mathrm{cm}^{-2}$ at a flow rate of $9.6 \mathrm{~mL} \mathrm{~min} \mathrm{~m}^{-1}$ ) throughout the straight main channel and the region of non-uniform shear stress at the outer walls of

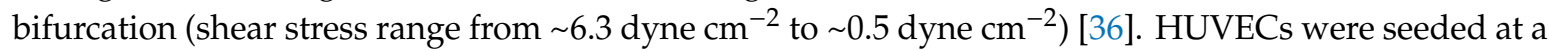
concentration of $7 \times 10^{5} \mathrm{~mL}^{-1}$ within the bifurcating slides and grown until $90-95 \%$ confluence, resulting in a cell monolayer. The cells were then perfused using a programmed peristaltic pump (Ismatec, Wertheim, Germany). The slide channel was perfused with medium (with or without polyR-Fe $\mathrm{O}_{3}$ particles at $100 \mu \mathrm{g} \mathrm{mL}^{-1}$ and $400 \mu \mathrm{g} \mathrm{mL} \mathrm{g}^{-1}$ ) at arterial shear stress for $18 \mathrm{~h}$. The slides were detached from the peristaltic pump system after $18 \mathrm{~h}$ and were washed with PBS buffer. Subsequently they were fixed with $4 \%$ formalin for $10 \mathrm{~min}$ at room temperature and the HUVECs cytoskeleton was stained using an Alexa488-phalloidin (PromoKine, Heidelberg, Germany). For cell nuclei counterstaining, a Hoechst staining (Molecular Probes, Darmstadt, Germany) was used. The experiments were performed in triplicates.

\subsection{Biomedical Applications}

\subsubsection{MRI}

The potential of polyR- $\mathrm{Fe}_{3} \mathrm{O}_{4}$ particles as contrast enhancement in magnetic resonance was estimated based on their longitudinal and transversal relaxivity values. T1- and T2-relaxation times of aqueous dispersions of polyR- $-\mathrm{Fe}_{3} \mathrm{O}_{4}$ at concentrations of $0.5,0.25$ and $0.1 \mathrm{mM}$ Fe were determined at $39^{\circ} \mathrm{C}$ using a nuclear magnetic resonance pulse spectrometer (miniSpec contrast agent analyzer mq40, Bruker Biospin, Ettlingen, Germany) running at $0.94 \mathrm{~T}$. The relaxivity $\mathrm{R}_{1}$ and $\mathrm{R}_{2}$ in $\left[\mathrm{L}(\mathrm{mmol} \mathrm{s})^{-1}\right.$ ] was determined by the slope of the reciprocal of the relaxation time $1 / \mathrm{T}_{\mathrm{i}}$ in $\left[\mathrm{s}^{-1}\right]$ as a function of the iron concentration $\mathrm{c}(\mathrm{Fe})$ in $\left[\mathrm{mmol} \mathrm{L}^{-1}\right]$ with the relaxation rate of the pure solvent $1 / \mathrm{T}_{\mathrm{i}}(0)\left[\mathrm{L}(\mathrm{mmol} \mathrm{s})^{-1}\right]$ as intercept according to the following equation:

$$
\frac{1}{T_{i}}=R_{i} * c(F e)+\frac{1}{T_{i(0)}}
$$

where $i=1,22$.

\subsubsection{Magnetic Properties and Hyperthermia}

Magnetic properties of liquid and powder samples were determined by means of vibrating sample magnetometry (VSM, micromag 3900, Princeton Measurements, Lake Shore Cryotronics, Westerville, OH, USA). The heating performance of liquid samples was measured within a magnetic field calorimeter as described before [36]. In short, the samples are placed in a solenoid generating an alternating magnetic field of about $410 \mathrm{kHz}$ and field amplitude of $25 \mathrm{kA} \mathrm{m}^{-1}$. The resulting temperature increase of the sample due to the magnetization reversal losses was measured using a fiberoptic temperature sensor, as function of heating time. Considering the particles concentration of the sample, the specific heating power of the particles was calculated from the recorded heating curves.

\subsubsection{MPI}

Magnetic particle imaging (MPI) is a medical imaging modality, where the spatial distribution of magnetic nanoparticles can be determined using a superposition of oscillating and static magnetic fields $[10,11]$. In contrast to MRI scans, a quantitative signal can be generated and real-time reconstruction speed reached. The fundamental signal generation process relies strongly on the magnetic characteristics of the used tracer, namely its non-linear magnetization curve. The suitability of a tracer for MPI measurements is determined in a magnetic particle spectrometer [12]. To evaluate the MPI efficacy, the magnetic particle spectrum (MPS) of the particle suspension was recorded at a drive field with an amplitude of $25 \mathrm{mT}$ and a frequency of $\mathrm{f}_{0}=25 \mathrm{kHz}$ using a commercial magnetic particle spectrometer system (Bruker BioSpin). The MPS of the previously approved contrast agent Resovist ${ }^{\circledR}$ was measured for comparison. Spectra were measured on $0.5 \mathrm{mM}$ Fe suspensions and 
subsequently normalized to $1 \mathrm{M}$ Fe. The magnetization amplitude ratio of the 3rd and 11th harmonic of sample and Resovist ${ }^{\circledR}(\mathrm{s} / \mathrm{R})$ was used for comparison.

\section{Results}

\subsection{Physicochemical Characterization of polyR-Magnetite Nanoparticles}

The TEM image of the polyR- $\mathrm{Fe}_{3} \mathrm{O}_{4}$ system shown in Figure 1a confirms the previously reported characterization, where the particles were about $40 \mathrm{~nm}$ in diameter and exhibited a flower-like morphology seemingly resulting from the aggregation of smaller units [26]. The hydrodynamic diameter, measured by dynamic light scattering (Figure 2), was determined to $\bar{d}=98 \mathrm{~nm}$ directly after synthesis. The mean hydrodynamic diameter and the size distribution does not change significantly over time and lies in the range of 100-130 nm after 8 months, which indicates colloidal stability over time as corroborated by the photograph (Figure 1b).
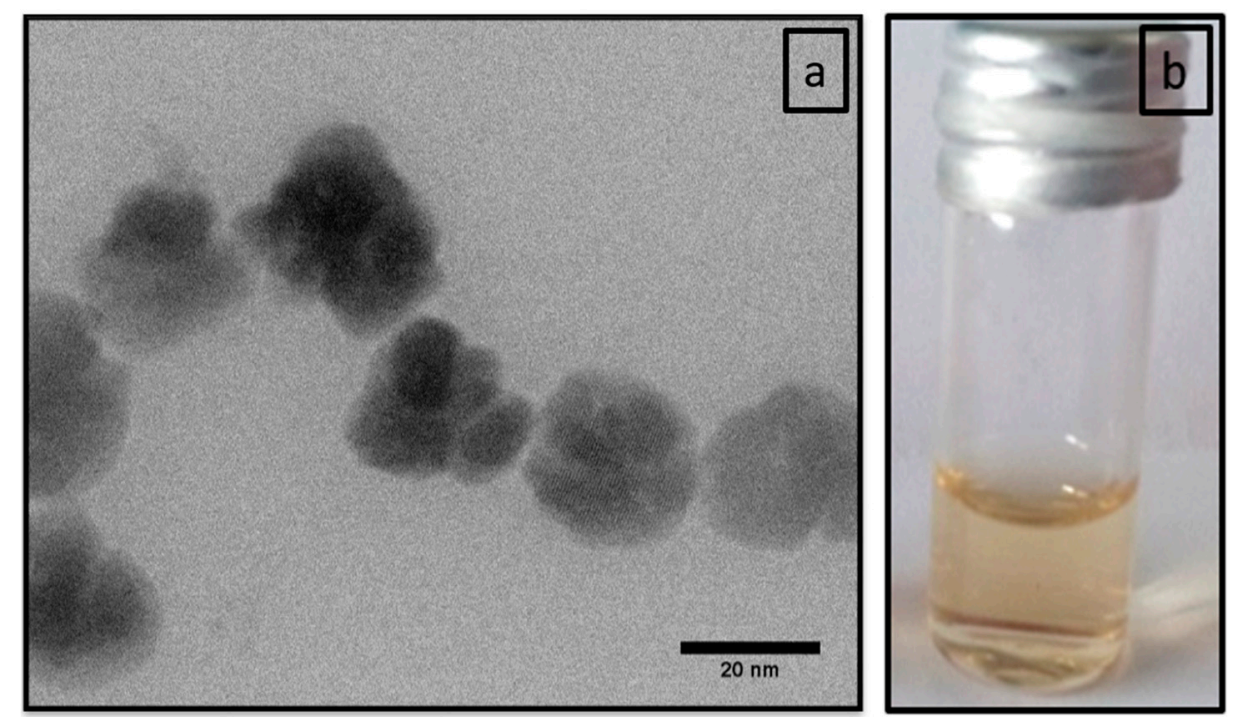

Figure 1. (a) STEM image of polyR-Fe $\mathrm{O}_{4}$ nanoparticles. (b) Image of vial with colloidal stable polyR-Fe ${ }_{3} \mathrm{O}_{4}$ nanoparticles solution one year after synthesis.

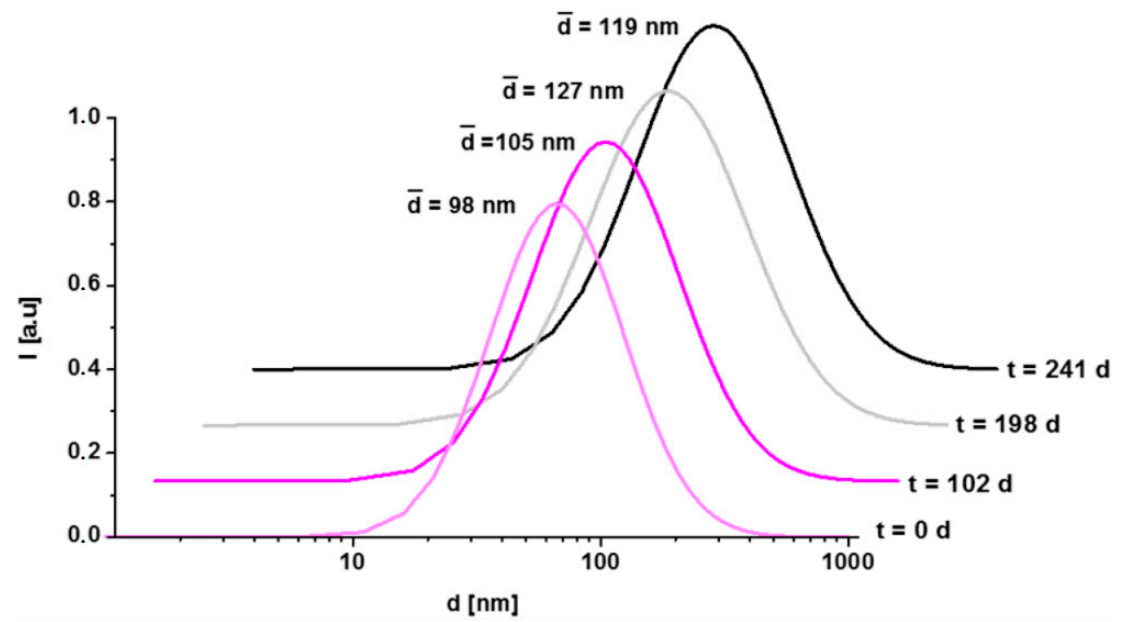

Figure 2. Intensity-weighted log-normal distribution of the hydrodynamic diameter of poly $-\mathrm{Fe}_{3} \mathrm{O}_{4}$ at different time points after synthesis. The mean hydrodynamic diameter $\bar{d}$ is displayed for comparison. 


\subsection{Biocompatibility}

The potential toxicity of nanoparticles is of high concern, especially if they are aimed for diagnostic purposes. In case of nanosystems intended for intravascular applications, endothelial cells are the first-contact cells. Therefore, we tested the effects of polyR- $\mathrm{Fe}_{3} \mathrm{O}_{4}$ on the viability of endothelial cells. For this purpose, HUVECs, which are an established model system for the human endothelium, were incubated with polyR-Fe $\mathrm{O}_{4}$ particles and with the contrast agent Resovist ${ }^{\circledR}$ as a control [37]. Two complementing methods, real-time cell analysis and live-cell microscopy, where used to assess the biocompatibility of polyR- $\mathrm{Fe}_{3} \mathrm{O}_{4}$ particles with endothelial cells under static conditions. To mimic more precisely the biological situation after intravascular injection of the nanoparticles into the bloodstream, a bifurcating-flow through model was used to further analyze the effects of the tested nanoparticle system on endothelial cell monolayer in a dynamic culture.

\subsubsection{Static Cell Viability Assays}

The label-free real-time cell analysis method suitable for nanotoxicity studies was used to monitor cell viability. The cell index of untreated, healthy endothelial cells increased continuously over time as seen in Figure 3. When HUVECs were treated with polyR-Fe $\mathrm{O}_{4}$, the particles were well tolerated up to concentrations of $50 \mu \mathrm{g} \mathrm{mL}^{-1}$. No significant differences in growth curves were detected in comparison to the control samples up to that concentration. In HUVECs treated with $100 \mu \mathrm{g} \mathrm{mL}^{-1}$ polyR-Fe $\mathrm{O}_{4}$, an inhibition of cell growth was detected, with a significantly reduced cell index already after $24 \mathrm{~h}$ (Figure 3).

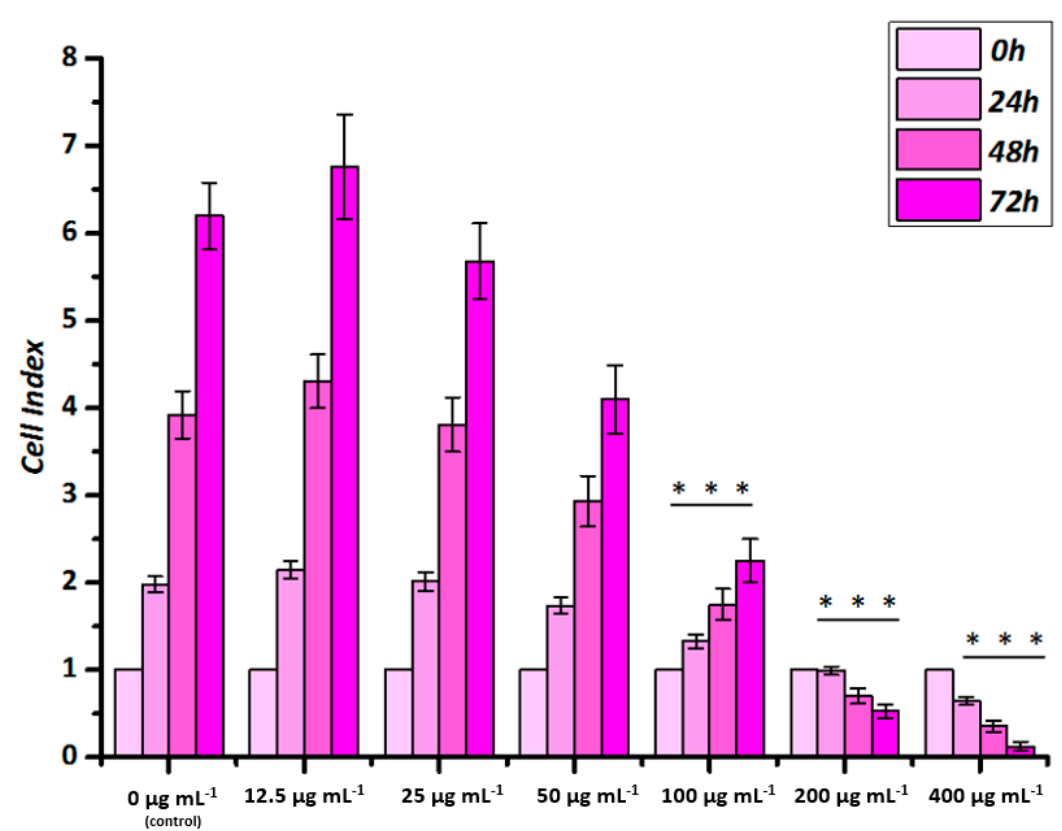

Figure 3. Biological effects of polyR- $\mathrm{Fe}_{3} \mathrm{O}_{4}$ particles on endothelial cells grown in static conditions analyzed by real-time cell analysis. HUVECs were seeded $24 \mathrm{~h}$ before nanoparticle application. After the initial $24 \mathrm{~h}$, particles at different concentrations were added and cell index was monitored for up to $72 \mathrm{~h}$ post application. Cell Index is displayed as $\mathrm{x}$-fold of untreated controls. Data are expressed as mean \pm SEM of $n=3$ experiments performed in hexaplicate, ${ }^{* * *} p<0.001$ vs. corresponding control (One-way Anova).

These values indicate that although the polyR- $\mathrm{Fe}_{3} \mathrm{O}_{4}$ does not induce endothelial cell death at $100 \mu \mathrm{g} \mathrm{mL}^{-1}$, they have a considerable inhibitory effect on cell growth and or attachment strength at this concentration. The treatment with 200 and $400 \mu \mathrm{g} \mathrm{mL}{ }^{-1}$ resulted in a strong and significant decrease of the cell index at $24 \mathrm{~h}, 48 \mathrm{~h}$ and $72 \mathrm{~h}$ even below the initial values, which indicates toxicity 
and cell death. In comparison, the reference agent Resovist ${ }^{\circledR}$ induced a slight growth inhibition at $100 \mu \mathrm{g} \mathrm{mL} \mathrm{m}^{-1}$ after $72 \mathrm{~h}$ and resulted in growth arrest in HUVECs at 200 and $400 \mu \mathrm{g} \mathrm{mL}^{-1}$ (Figure S1).

To validate the results of the real-time cell analysis, live-cell microscopy was performed using the IncuCyte ${ }^{\circledR}$ FLR system. No difference in confluence (i.e., the number of adherent cells relating to the surface area covered by cells), between polyR- $\mathrm{Fe}_{3} \mathrm{O}_{4}$ treated cells and the untreated control was observed at concentrations up to $100 \mu \mathrm{g} \mathrm{mL}^{-1}$ during the treatment for up to $72 \mathrm{~h}$. A decrease in confluence was detected in samples treated with 200 and $400 \mu \mathrm{g} \mathrm{mL} \mathrm{L}^{-1}$ polyR-Fe $\mathrm{O}_{4}$. However, some cell elongation was observed at $50 \mu \mathrm{g} \mathrm{mL}^{-1}$ (Figure 4) and was more pronounced at higher concentrations, which was not observable in Resovist ${ }^{\circledR}$-treated cells (Figure S2). Combining the results of real-time cell analysis and live-cell imaging, it can be concluded that the decrease in cell index induced by $100 \mu \mathrm{g} \mathrm{mL}-1$ of polyR-Fe $\mathrm{O}_{4}$ was not due to decreased endothelial cell viability but rather due to decreased cell adherence, as no changes in confluence were observed at this concentration with IncuCyte. The nanoparticle-induced alteration in cell morphology is most likely affecting the cell index, as previously described [29].
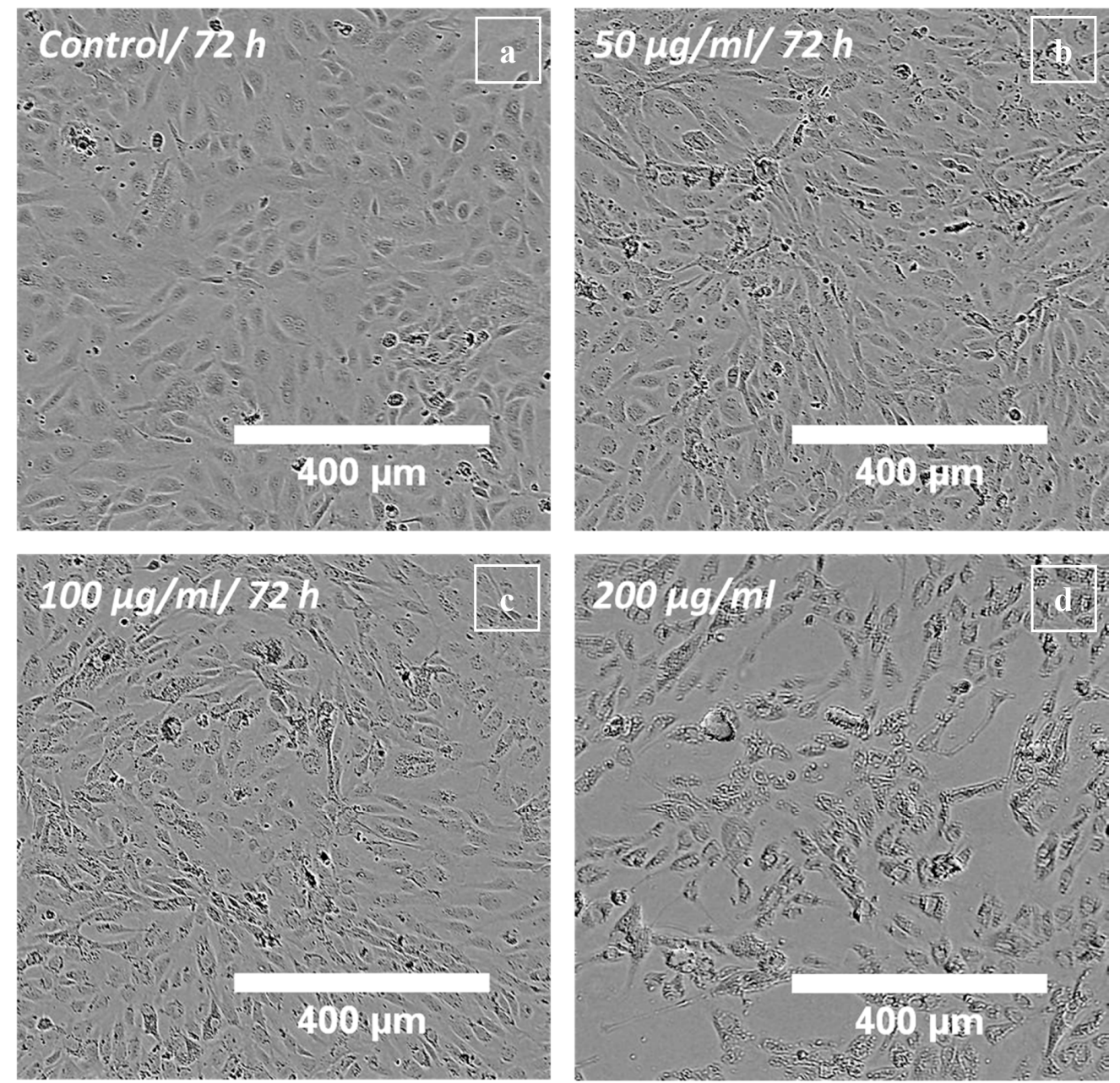

Figure 4. Live-cell microscopy of HUVECs treated with polyR-Fe $\mathrm{O}_{4}$ : Phase contrast images of HUVECs were taken after $72 \mathrm{~h}$ post particle addition. (a) Untreated control HUVECs, (b) HUVECs treated with $50 \mu \mathrm{g} \mathrm{mL}{ }^{-1}$, (c) HUVECs treated with $100 \mu \mathrm{g} \mathrm{mL}{ }^{-1}$ and (d) HUVECs treated with $200 \mu \mathrm{g} \mathrm{mL}^{-1}$ polyR-Fe $\mathrm{O}_{4}$. Representative images of $n=3$ experiments and hexaplicate samples are shown.

\subsubsection{Dynamic Cell Viability}

In dynamic experiments in vitro, the toxic effects of circulating substances can manifest themselves as endothelial cell shrinking and detachment. The viability and the confluence, as well as the 
cell morphology and cell-cell contacts upon nanoparticle treatment can thus be analyzed by immunofluorescent staining. Figure 5 shows the effects of circulating polyR- $\mathrm{Fe}_{3} \mathrm{O}_{4}$ particles on endothelial cells grown in the bifurcating flow-through channels. As compared with the dynamic control experiments without any circulating nanoparticles (Figure 5a), treatment of HUVECs with $100 \mu \mathrm{g} \mathrm{mL}^{-1}$ polyR-Fe $\mathrm{O}_{4}$ had no effect either on cell numbers nor on morphology under laminar or non-uniform shear stress conditions (Figure 5b). Within HUVECs exposed to $400 \mu \mathrm{g} \mathrm{mL}^{-1}$ circulating polyR-Fe $\mathrm{O}_{4}$ for $18 \mathrm{~h}$, a significant decrease in cell numbers under laminar shear stress was observed. This effect was further pronounced under non-uniform shear stress conditions, where the cell detachment areas were observed (Figure $5 \mathrm{c}$ ). This was additionally confirmed with the confluence quantification for non-uniform and laminar shear stress regions of the channels shown in SI Figure S3.

\section{Laminar}
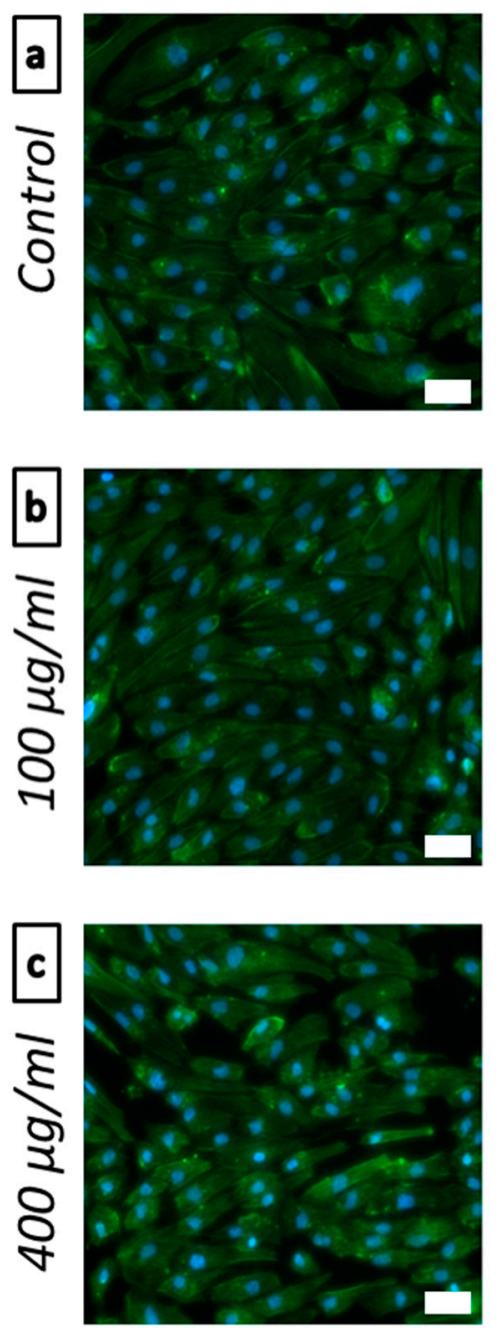

Non-uniform
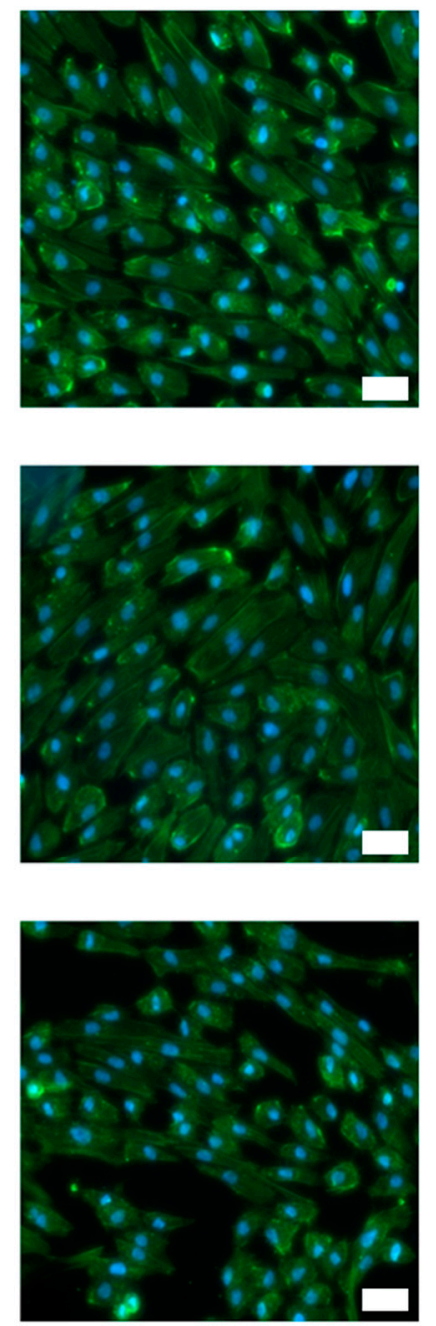

Figure 5. Effects of circulating polyR- $\mathrm{Fe}_{3} \mathrm{O}_{4}$ on enthodelial cell grown under flow conditions. HUVECs were grown in bifurcating slides until confluence and perfused with polyR- $\mathrm{Fe}_{3} \mathrm{O}_{4}$-containing medium for $18 \mathrm{~h}$. The representative laminar and non-uniform regions are shown after fluorescent staining. Nuclei are visualized using a Hoechst 33342 (blue) staining, whereas F-actin is visualized with Alexa 488-conjugated phalloidin (green). Representative images of $n=3$ experiments are shown. (Scale bars: $50 \mu \mathrm{m}$ ). 


\subsection{Biomedical Applications}

\subsubsection{MRI Contrast Agents}

Colloidal stability of the particles is mandatory for the determination of relaxation times and finally, for their use as MRI contrast agents. Besides the DLS measurements (Figure 2), the concentration-dependent relaxation rates 1/T1 and 1/T2 in Figure 6 showed good linearity within the measured concentration range, which is an indication of non-agglomerating particles and overall colloidal stability. PolyR-Fe $\mathrm{O}_{4}$ exhibit relaxivity values of $\mathrm{R} 1=8.5$ and $\mathrm{R} 2=145.7 \mathrm{~L}(\mathrm{mmol} \mathrm{s})^{-1}$, which yields a R2/R1 ratio of 17.0 .

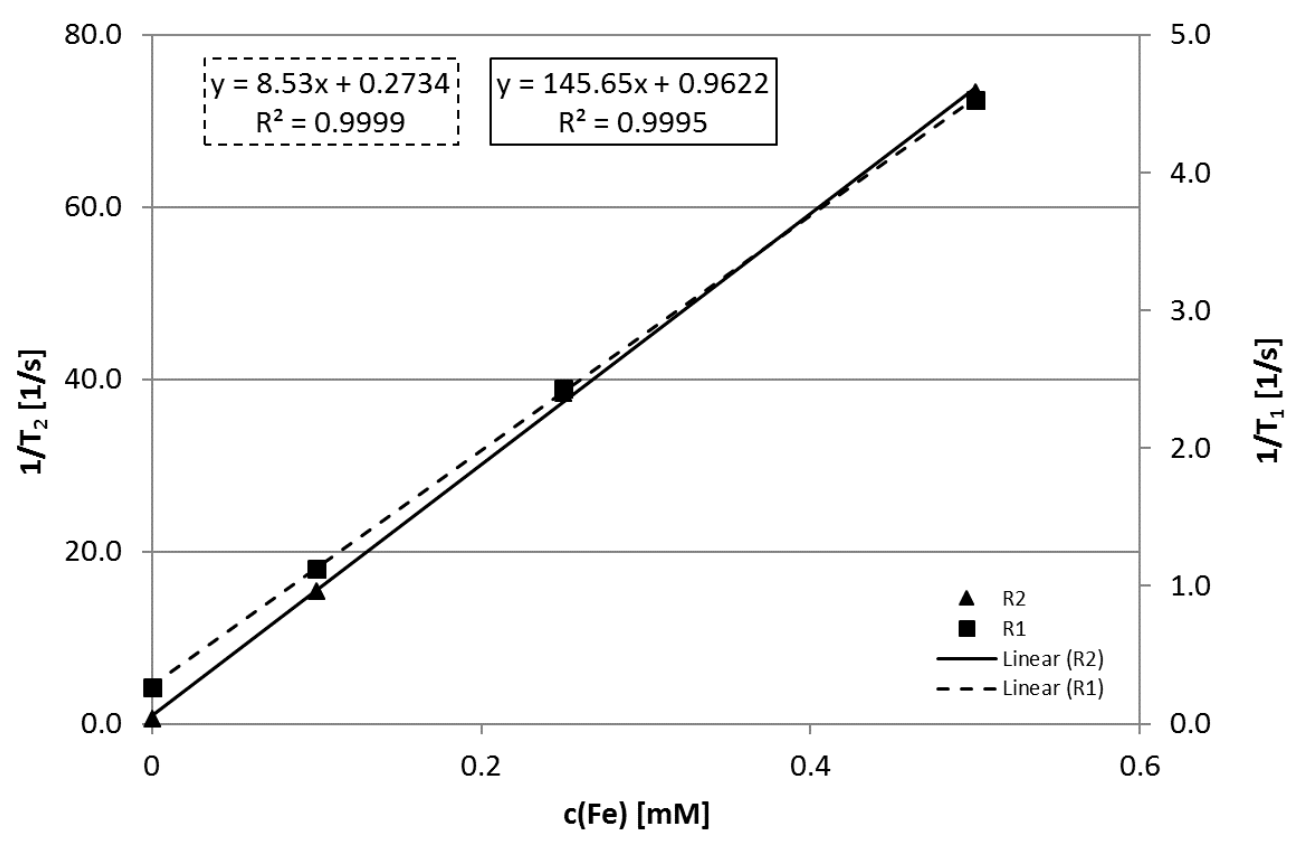

Figure 6. Relationship of the iron concentration $\mathrm{c}(\mathrm{Fe})$ in $[\mathrm{mM}]$ and the reciprocal of the relaxation time $1 / \mathrm{T}_{1,2}$ in $[1 / \mathrm{s}]$. The relaxivities $\mathrm{R} 1$ and $\mathrm{R} 2$ were calculated using the slope of the obtained linear equation.

\subsubsection{Hyperthermia}

To evaluate polyR- $\mathrm{Fe}_{3} \mathrm{O}_{4}$ for their possible application in magnetic hyperthermia, the specific heating power (SHP) of polyR- $\mathrm{Fe}_{3} \mathrm{O}_{4}$ was measured and yielded $208 \mathrm{~W} \mathrm{~g}^{-1}$, recorded at $410 \mathrm{kHz}$, (altering field frequency) and $25 \mathrm{kA} \mathrm{m}^{-1}$ (magnetic field strength). The measured value is comparable to the results of particles development for hyperthermia of other groups and the prepared polyR-Fe $\mathrm{O}_{4}$ particles are promising for application in magnetic particle hyperthermia experiments [36].

\subsubsection{MPI}

Two features of MPS spectra are typically considered as fundamental in order to judge the usability of the measured particles for MPI. The first feature is the total amplitude of the third harmonic and the second is the largest frequency that can be distinguished from the noise. In our measurements, the third harmonic of polyR- $\mathrm{Fe}_{3} \mathrm{O}_{4}$ was 1.7 higher than the signal acquired from Resovist ${ }^{\circledR}$ (Figure 7). Our particles outperformed the control until the seventeenth harmonic, where the signal was about 1.35 higher than that of Resovist ${ }^{\circledR}$ (Figure 7). 


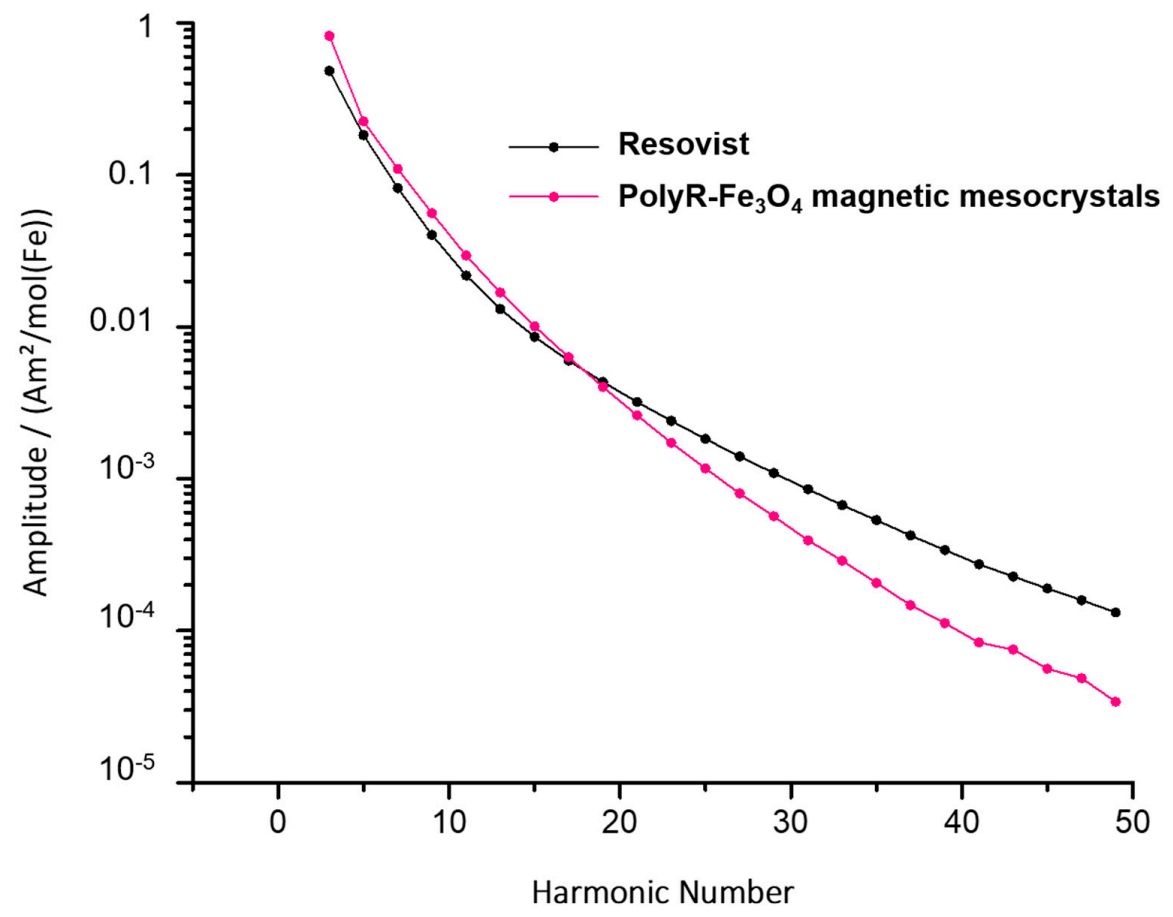

Figure 7. MPS measurement of polyR- $\mathrm{Fe}_{3} \mathrm{O}_{4}$ particles (pink) and Resovist ${ }^{\circledR}$ (black) as comparison.

\section{Discussion}

\subsection{Biocompatibility}

Nanoparticles, including polyR- $\mathrm{Fe}_{3} \mathrm{O}_{4}$ exhibit a large surface area to volume ratio and therefore, are considered chemically reactive in comparison to bulk materials [38]. Undesirable reactions could occur upon their administration in vivo, which usually depend on the material composition. Therefore, polyR-Fe $\mathrm{O}_{4}$ particles were tested in static and dynamic conditions on cellular system in vitro and indeed showed effects but limited on cells, such as influence in cell adherence and therefore decreasing cell viabilities under static conditions. The viability of primary endothelial cells was not affected up to $100 \mu \mathrm{g} \mathrm{mL}^{-1}$ and cytotoxic effects were only observed when using high nanoparticle concentrations (larger than $200 \mu \mathrm{g} \mathrm{mL}{ }^{-1}$ ). Consequently, the polyR-Fe ${ }_{3} \mathrm{O}_{4}$ particles were well tolerated in static conditions at moderate concentrations (up to $100 \mu \mathrm{g} \mathrm{mL}^{-1}$ ) and they exhibited comparable in vitro biocompatibility as the reference product Resovist ${ }^{\circledR}$. For colon carcinoma cell imaging for example, the amount of Fe needed is only about $4-5 \mu \mathrm{g} / 10^{6}$ cells [39], which is much lower than what is used for the biocompatibility assay we used. In addition, the polyR- $\mathrm{Fe}_{3} \mathrm{O}_{4}$ biocompatibility was even improved under dynamic conditions as compared to static conditions. Whereas the particles at $400 \mu \mathrm{g} \mathrm{mL}-1$ were highly toxic under static conditions, only a minor decrease in cell numbers was observed at this concentration under flow.

A variety of nanoparticles consisting of different materials were previously tested regarding their cytotoxicity and biocompatibility using the same experimental set up [35], [40]. In these static cell culture assays, one type of polymeric nanoparticles showed cytotoxic effects at a concentration of $50 \mu \mathrm{g} \mathrm{mL}^{-1}$ [35]. Among iron oxide nanoparticles, some SPIONs showed a tendency for cell growth inhibition at the same concentration of $50 \mu \mathrm{g} \mathrm{mL}^{-1}$, with negative effects on cell viability or adherence at $100 \mu \mathrm{g} \mathrm{mL} \mathrm{mL}^{-1}$ [35]. In contrast, other types of SPIONs were well tolerated by endothelial cells up to $400 \mu \mathrm{g} \mathrm{mL}^{-1}$ in static conditions [35], indicating that considerable differences in biocompatibility are possible among the same class of nanomaterials, likely depending on their physical characteristics and coating composition. Our polyR- $\mathrm{Fe}_{3} \mathrm{O}_{4}$ nanoparticles showed the first inhibitory effects on endothelial viability from $200 \mu \mathrm{g} \mathrm{mL}^{-1}$ on, which indicates good biocompatibility in the light of clinically-relevant concentrations. In dynamic cell culture conditions, polymeric nanoparticles 
comprised already negative effects on endothelial cells at a concentration of $100 \mu \mathrm{g} \mathrm{mL}^{-1}$ [35]. In contrast, other particle types (e.g., lipid nanoparticles and iron oxide nanoparticles) were tolerated better under flow as compared to static culture [35]. The polyR-Fe $\mathrm{O}_{4}$ nanoparticles showed a comparable promising performance within dynamic cell culture conditions.

\subsection{Biomedical Applications}

Superparamagnetic substances such as iron oxide nanoparticles typically reduce the relaxation times T1 and T2 of hydrogen protons in the surrounding tissue. The performance of polyR-Fe $\mathrm{O}_{4}$ nanoparticles as a potential MRI contrast agent was previously compared to Resovist ${ }^{\circledR}$, showing that the $\mathrm{R} 2 / \mathrm{R} 1$ ratio of 17 is higher in polyR-Fe $\mathrm{O}_{4}$ as compared to that of Resovist ${ }^{\circledR}(\mathrm{R} 2 / \mathrm{R} 1=11)$ [14]. Contrast agents with higher R2/R1 ratios include electrostatically L-DOPA stabilized iron oxide nanoparticles with significantly larger core diameter [14] or magnetosomes with dimensions similar to the nanoparticles studied here. However, these nanoparticles either have to be stabilized in a time-consuming procedure after synthesis, or originate from an expensive and time-consuming growth of magnetotactic bacteria, differing from the rapid approach of our synthetic route.

Magnetite nanoparticles encapsulated in cationic liposomes were clinically approved in Europe for the hyperthermia treatment of glioblastoma [41]. In hyperthermia, the magnetic properties of nanoparticles are transferred into heat and dissipated to the surrounding environment, whereas the released energy of particles is corresponding to a hysteresis loop. It is described that the dissipated heat of a magnetite nanoparticle is dependent upon its size and composition, but furthermore, upon the frequency the temperature of the applied field [42]. The polyR-Fe $\mathrm{O}_{4}$ achieve 2.5 times higher specific heating power (SHP) than a previously approved contrast agent ferumoxides (Endorem/Feridex ${ }^{\circledR}$ ) (208 $\mathrm{W} \mathrm{g}^{-1}$ vs. $83 \mathrm{~W} \mathrm{~g}^{-1}$ ) [10]. Several studies suggested, that the heating capacity of magnetic nanoparticles can be improved, by means of variation in size, shape and iron content of nanoparticles. Two types of iron oxide nanoparticles, i.e., spherical and cubic shaped nanoparticles, were investigated in a recent comparative study to evaluate their inductive heating capacities [43]. These two types of nanoparticles were produced in two distinct average volumes and sizes. In case of smaller size of nanoparticles, the cubic nanoparticles were shown to heat better compared to spherical particles. An opposite trend was observed for larger nanoparticles, whereby the cubic nanoparticles showed a better heating capacity that the spherical ones. Furthermore, the more effective heating efficiency of the small sized cubic magnetic nanoparticles could be attributed to the formation of chain-like aggregates and an additionally enhanced anisotropy. The larger sized cubic magnetic nanoparticles showed less efficiency due to the strong aggregation of those magnetic nanoparticles [43]. PolyR-Fe $\mathrm{O}_{4}$ showed very promising heating efficiency, probably due to their chain formation as reported for magnetosomes, the biogenic magnetite nanoparticles from magnetotactic bacteria, which show highly increased heating efficiency in comparison to single magnetite nanoparticles [29]. Additionally, polyR- $\mathrm{Fe}_{3} \mathrm{O}_{4}$ nanoparticles comprise an interesting flower-like internal structure within each magnetic nanoparticle. Hence, the particles themselves are more spherical-like than cubic e.g., as it was shown that physical motion contributes to the heating efficiency, spherical shaped particles have advantage over the cubic ones, when dispersed in water [43]. Additionally, it is known that single crystalline nanoparticles exhibit higher heating capacities than polycrystalline nanoparticles [44]. We have previously shown that polyR- $\mathrm{Fe}_{3} \mathrm{O}_{4}$ are single crystalline, even though they possess a very special internal structure [26]. In conclusion, our polyR- $\mathrm{Fe}_{3} \mathrm{O}_{4}$ nanoparticles represent ideal candidates for further investigations in magnetic hyperthermia, as they fulfill all criteria to reach high heating capacities, both theoretically and in practice.

PolyR- $\mathrm{Fe}_{3} \mathrm{O}_{4}$ nanoparticles are not solely promising candidates for MRI contrast agents or magnetic hyperthermia, but they also possess interesting capacities for MPI. In general, the MPI signal originates directly from the tracer, whereby mainly iron oxide nanoparticles are used. The magnetic moment of iron oxide nanoparticles is about eight orders of magnitude larger than that of protons, measured by MRI, whereas with MPI, the detected magnetization is approximately 22 million times 
stronger than that measured with MRI at $7 \mathrm{~T}$. To be suitable for MPI, nanoparticles must possess particular physical and magnetic properties. The theoretical limit was calculated that must be achieved using nanoparticles with a diameter of around $30 \mathrm{~nm}$ [26]. So far, Resovist ${ }^{\circledR}$ was used as the "gold standard" in MPI, but did not succeed in a satisfying signal [26]. The non-ideal MPI signal of Resovist ${ }^{\circledR}$ is related to the large fraction of particles with very small core diameters and low magnetic moments. Our polyR- $\mathrm{Fe}_{3} \mathrm{O}_{4}$ exhibited higher signals in their $3 \mathrm{rd}$ (1.7 times) and 11th harmonic (1.35 times) when compared to Resovist ${ }^{\circledR}$. They thus showed all needed features for a promising MPI performance, such as monodispersity, ideal sizes, single crystallinity and the ability of chain formation. Additionally, polyR magnetic nanoparticles are positively charged, which may be of additional advantage as they can be internalized by cells easily [26,45], which would guarantee a better distribution and rapid uptake for various biomedical applications [46].

\section{Conclusions}

In summary, the polyR- $\mathrm{Fe}_{3} \mathrm{O}_{4}$ nanoparticles described here represent promising candidates for biotechnological applications. The particle synthesis is straightforward. We show the particles are biocompatible and perform well as MRI contrast agents and for MPI. In addition, since the polyR-Fe $\mathrm{O}_{4}$ are positively charged and show high cell uptake, the particles are particularly suitable for magnetic hyperthermia and direct tumor therapy where the coating can be coupled with specific antibodies, to stimulate transport and uptake as well as recognition of tumor cells. Accordingly, we anticipate that polyR- $\mathrm{Fe}_{3} \mathrm{O}_{4}$ particles will become a model material with high theranostic potential.

Supplementary Materials: The following are available online at http://www.mdpi.com/2079-4991/10/10/2014/s1, Figure S1: Biological effects of Resovist ${ }^{\circledR}$ particles on endothelial cells grown in static conditions by real-time cell analysis, Figure S2: Live-cell microscopy of HUVECs treated with Resovist ${ }^{\circledR}$ particles, Figure S3: Semi-quantitative analysis of confluence in non-uniform and laminar regions of the bifurcating channels.

Author Contributions: Conceptualization, D.F. and V.E.R.; methodology, V.E.R., J.M., K.B., T.H., A.K. and S.D.; validation, D.F., I.C., A.K. and S.D; investigation, V.E.R., J.M., K.B., T.H., A.K., S.D.; writing-original draft preparation, D.F. and V.E.R; writing-review and editing, all authors; supervision, D.F., I.C., A.K. and S.D; funding acquisition, D.F. All authors have read and agreed to the published version of the manuscript.

Funding: Damien Faivre acknowledges funding from the Max Planck Society. This study was supported by the Deutsche Forschungsgemeinschaft within the Framework of ERA-Chem (Project Number FA 835/12-1) and in part by the EU ("NanoAthero" project FP7-NMP-2012-LARGE-6-309820).

Conflicts of Interest: The authors declare no conflict of interest.

\section{References}

1. Silva, A.K.; Espinosa, A.; Wilhelm, C.; Gazeau, F.; Kolosnjaj-Tabi, J. Medical Applications of Iron Oxide Nanoparticles. Iron Oxides 2016, 425-472. [CrossRef]

2. Hergt, R.; Dutz, S. Magnetic particle hyperthermia-Biophysical limitations of a visionary tumour therapy. J. Magn. Magn. Mater. 2007, 311, 187-192. [CrossRef]

3. Reichel, V.; Faivre, D. Magnetite Nucleation and Growth. In New Perspectives on Mineral Nucleation and Growth; Springer International Publishing: Cham, Switzerland, 2017; pp. 275-291. [CrossRef]

4. Yu, E.Y.; Bishop, M.; Zheng, B.; Ferguson, R.M.; Khandhar, A.P.; Kemp, S.J.; Krishnan, K.M.; Goodwill, P.W.; Conolly, S.M. Magnetic Particle Imaging: A Novel in Vivo Imaging Platform for Cancer Detection. Nano Lett. 2017, 17, 1648-1654. [CrossRef] [PubMed]

5. Shakeri, S.; Ashrafizadeh, M.; Zarrabi, A.; Roghanian, R.; Afshar, E.G.; Pardakhty, A.; Mohammadinejad, R.; Kumar, A.; Thakur, V.K. Multifunctional Polymeric Nanoplatforms for Brain Diseases Diagnosis, Therapy and Theranostics. Biomedicines 2020, 8, 13. [CrossRef]

6. Ramírez-Acosta, C.M.; Cifuentes, J.; Cruz, J.C.; Reyes, L.H. Patchy Core/Shell, Magnetite/Silver Nanoparticles via Green and Facile Synthesis: Routes to Assure Biocompatibility. Nanomaterials 2020, 10, 1857. [CrossRef]

7. Ateş, B.; Koytepe, S.; Ulu, A.; Gurses, C.; Thakur, V.K. Chemistry, Structures, and Advanced Applications of Nanocomposites from Biorenewable Resources. Chem. Rev. 2020, 120, 9304-9362. [CrossRef] 
8. Al-Kattan, A.; Ali, L.M.A.; Daurat, M.; Mattana, E.; Gary-Bobo, M. Biological Assessment of Laser-Synthesized Silicon Nanoparticles Effect in Two-Photon Photodynamic Therapy on Breast Cancer MCF-7 Cells. Nanomaterials 2020, 10, 1462. [CrossRef]

9. Dutz, S.; Hergt, R. Magnetic nanoparticle heating and heat transfer on a microscale: Basic principles, realities and physical limitations of hyperthermia for tumour therapy. Int. J. Hyperth. 2013, 29, 790-800. [CrossRef]

10. Bae, K.H.; Park, M.; Do, M.J.; Lee, N.; Ryu, J.H.; Kim, G.W.; Kim, C.; Park, T.G.; Hyeon, T.; Lee, J.S. Chitosan Oligosaccharide-Stabilized Ferrimagnetic Iron Oxide Nanocubes for Magnetically Modulated Cancer Hyperthermia. ACS Nano 2012, 6, 5266-5273. [CrossRef]

11. Kievit, F.M.; Zhang, M. Surface Engineering of Iron Oxide Nanoparticles for Targeted Cancer Therapy. Acc. Chem. Res. 2011, 44, 853-862. [CrossRef]

12. Szlezak, M.; Nieciecka, D.; Joniec, A.; Pękała, M.; Gorecka, E.; Emo, M.; Stébé, M.J.; Krysiński, P.; Bilewicz, R. Monoolein Cubic Phase Gels and Cubosomes Doped with Magnetic Nanoparticles-Hybrid Materials for Controlled Drug Release. ACS Appl. Mater. Interfaces 2017, 9, 2796-2805. [CrossRef] [PubMed]

13. Mohapatra, S.; Mallick, S.K.; Maiti, T.K.; Ghosh, S.K.; Pramanik, P. Synthesis of highly stable folic acid conjugated magnetite nanoparticles for targeting cancer cells. Nanotechnology 2007, 18, 385102. Available online: http://stacks.iop.org/0957-4484/18/i=38/a=385102 (accessed on 11 October 2020). [CrossRef]

14. Taukulis, R.; Widdrat, M.; Kumari, M.; Heinke, D.; Rumpler, M.; Uebe, R.; Tompa, É.; Kraupner, A.; Cebers, A.; Schüler, D.; et al. Magnetic iron oxide nanoparticles as MRI contrast agents-A comprehensive physical and theoretical study. Magnetohydrodynamics 2015, 51, 721-748. Available online: http://real.mtak.hu/34358/ (accessed on 4 June 2018). [CrossRef]

15. Busquets, M.A.; Estelrich, J.; Sánchez-Martín, M.J. Nanoparticles in magnetic resonance imaging: From simple to dual contrast agents. Int. J. Nanomed. 2015, 10, 1727. [CrossRef]

16. Sharma, V.K.; Alipour, A.; Soran-Erdem, Z.; Aykut, Z.G.; Demir, H.V. Highly monodisperse low-magnetization magnetite nanocubes as simultaneous T1-T2 MRI contrast agents. Nanoscale 2015, 7, 10519-10526. [CrossRef] [PubMed]

17. Dutz, S.; Kettering, M.; Hilger, I.; Muller, R.; Zeisberger, M. Magnetic multicore nanoparticles for hyperthermia-Influence of particle immobilization in tumour tissue on magnetic properties. Nanotechnology 2011, 22, 265102. [CrossRef] [PubMed]

18. Dutz, S. Are Magnetic Multicore Nanoparticles Promising Candidates for Biomedical Applications? IEEE Trans. Magn. 2016, 52, 1-3. [CrossRef]

19. Prozorov, T.; Mallapragada, S.K.; Narasimhan, B.; Wang, L.; Palo, P.; Nilsen-Hamilton, M.; Williams, T.J.; Bazylinski, D.A.; Prozorov, R.; Canfield, P.C. Protein-Mediated Synthesis of Uniform Superparamagnetic Magnetite Nanocrystals. Adv. Funct. Mater. 2007, 17, 951-957. [CrossRef]

20. Baumgartner, J.; Carillo, M.A.; Eckes, K.M.; Werner, P.; Faivre, D. Biomimetic Magnetite Formation: From Biocombinatorial Approaches to Mineralization Effects. Langmuir 2014, 30, 2129-2136. [CrossRef]

21. Arakaki, A. A Novel Protein Tightly Bound to Bacterial Magnetic Particles in Magnetospirillum magneticum Strain AMB-1. J. Biol. Chem. 2003, 278, 8745-8750. [CrossRef]

22. Bereczk-Tompa, É.; Pósfai, M.; Tóth, B.; Vonderviszt, F. Magnetite-Binding Flagellar Filaments Displaying the MamI Loop Motif. ChemBioChem 2016, 17, 2075-2082. [CrossRef] [PubMed]

23. Jehle, F.; Valverde-Tercedor, C.; Reichel, V.; Carillo, M.A.; Bennet, M.; Günther, E.; Wirth, R.; Mickoleit, F.; Zarivach, R.; Schüler, D.; et al. Genetically Engineered Organization: Protein Template, Biological Recognition Sites, and Nanoparticles. Adv. Mater. Interfaces 2017, 4, 1600285. [CrossRef]

24. Rawlings, A.E.; Bramble, J.P.; Tang, A.; Somner, L.A.; Monnington, A.E.; Cooke, D.; McPherson, M.J.; Tomlinson, D.C.; Staniland, S.S. Phage display selected magnetite interacting Adhirons for shape controlled nanoparticle synthesis. Chem. Sci. 2015, 6, 5586-5594. [CrossRef] [PubMed]

25. Lenders, J.J.M.; Zope, H.R.; Yamagishi, A.; Bomans, P.H.; Arakaki, A.; Kros, A.; De With, G.; Sommerdijk, N.A.J.M. Bioinspired Magnetite Crystallization Directed by Random Copolypeptides. Adv. Funct. Mater. 2015, 25, 711-719. [CrossRef]

26. Reichel, V.; Kovács, A.; Kumari, M.; Bereczk-Tompa, É.; Schneck, E.; Diehle, P.; Pósfai, M.; Hirt, A.M.; Duchamp, M.; Dunin-Borkowski, R.; et al. Single crystalline superstructured stable single domain magnetite nanoparticles. Sci. Rep. 2017, 7, 45484. [CrossRef]

27. Faivre, D.; Godec, T.U. From Bacteria to Mollusks: The Principles Underlying the Biomineralization of Iron Oxide Materials. Angew. Chemie Int. Ed. 2015, 54, 4728-4747. [CrossRef] 
28. Mannucci, S.; Ghin, L.; Conti, G.; Tambalo, S.; Lascialfari, A.; Orlando, T.; Benati, N.; Bernardi, P.; Betterle, N.; Bassi, R.; et al. Magnetic Nanoparticles from Magnetospirillum gryphiswaldense Increase the Efficacy of Thermotherapy in a Model of Colon Carcinoma. PLoS ONE 2014, 9, e108959. [CrossRef]

29. Alphandéry, E.; Faure, S.; Seksek, O.; Guyot, F.; Chebbi, I. Chains of Magnetosomes Extracted from AMB-1 Magnetotactic Bacteria for Application in Alternative Magnetic Field Cancer Therapy. ACS Nano 2011, 5, 6279-6296. [CrossRef]

30. Lisy, M.R.; Hartung, A.; Lang, C.; Schüler, D.; Richter, W.; Reichenbach, J.R.; A Kaiser, W.; Hilger, I. Fluorescent Bacterial Magnetic Nanoparticles as Bimodal Contrast Agents. Investig. Radiol. 2007, 42, 235-241. [CrossRef]

31. Kraupner, A.; Eberbeck, D.; Heinke, D.; Uebe, R.; Schüler, D.; Briel, A. Bacterial magnetosomes-Nature's powerful contribution to MPI tracer research. Nanoscale 2017, 9, 5788-5793. [CrossRef]

32. Lee, H.Y.; Mohammed, K.A.; Nasreen, N. L-Arginine-Incorporated Albumin Mesospheres: A Drug Delivery System for Cancer Therapy. In L-Arginine in Clinical Nutrition; Springer International Publishing: Cham, Switzerland, 2017; pp. 527-541. [CrossRef]

33. Vazdar, M.; Heyda, J.; Mason, P.E.; Tesei, G.; Allolio, C.; Lund, M.; Jungwirth, P. Arginine "Magic": Guanidinium Like-Charge Ion Pairing from Aqueous Salts to Cell Penetrating Peptides. Acc. Chem. Res. 2018, 51, 1455-1464. [CrossRef] [PubMed]

34. Baumgartner, J.; Bertinetti, L.; Widdrat, M.; Hirt, A.M.; Faivre, D. Formation of Magnetite Nanoparticles at Low Temperature: From Superparamagnetic to Stable Single Domain Particles. PLoS ONE 2013, 8, e57070. [CrossRef]

35. Matuszak, J.; Baumgartner, J.; Zaloga, J.; Juenet, M.; Silva, A.E.; Franke, D.; Almer, G.; Texier, I.; Faivre, D.; Metselaar, J.M.; et al. Nanoparticles for intravascular applications: Physicochemical characterization and cytotoxicity testing. Nanomedicine 2016, 11, 597-616. [CrossRef] [PubMed]

36. Dutz, S.; Hergt, R. Magnetic particle hyperthermia-A promising tumour therapy? Nanotechnology 2014, 25, 452001. [CrossRef] [PubMed]

37. Nordling, S.; Nilsson, B.; Magnusson, P. A novel in vitro model for studying the interactions between human whole blood and endothelium. J. Vis. Exp. 2014, e52112. [CrossRef] [PubMed]

38. Lee, N.; Yoo, D.; Ling, D.; Cho, M.H.; Hyeon, T.; Cheon, J. Iron Oxide Based Nanoparticles for Multimodal Imaging and Magnetoresponsive Therapy. Chem. Rev. 2015, 115, 10637-10689. [CrossRef]

39. Pinkernelle, J.G.; Teichgräber, U.K.M.; Neumann, F.; Lehmkuhl, L.; Ricke, J.; Scholz, R.; Jordan, A.; Bruhn, H. Imaging of single human carcinoma cells in vitro using a clinical whole-body magnetic resonance scanner at 3.0 T. Magn. Reson. Med. Off. J. Int. Soc. Magn. Reason. Med. 2005, 53, 1187-1192. [CrossRef]

40. Matuszak, J.; Dörfler, P.; Lyer, S.; Unterweger, H.; Juenet, M.; Chauvierre, C.; Alaarg, A.; Franke, D.; Almer, G.; Texier, I.; et al. Comparative analysis of nanosystems' effects on human endothelial and monocytic cell functions. Nanotoxicology 2018, 12, 957-974. [CrossRef]

41. Sun, J.; Guo, M.; Pang, H.; Qi, J.; Zhang, J.; Ge, Y. Treatment of malignant glioma using hyperthermia. Neural Regen. Res. 2013, 8, 2775.

42. Chiu-Lam, A.; Rinaldi, C. Nanoscale Thermal Phenomena in the Vicinity of Magnetic Nanoparticles in Alternating Magnetic Fields. Adv. Funct. Mater. 2016, 26, 3933-3941. [CrossRef]

43. Nemati, Z.; Das, R.; Alonso, J.; Clements, E.; Phan, M.H.; Srikanth, H. Iron Oxide Nanospheres and Nanocubes for Magnetic Hyperthermia Therapy: A Comparative Study. J. Electron. Mater. 2017, 46, 3764-3769. [CrossRef]

44. Iacovita, C.; Florea, A.; Dudric, R.; Páll, E.; Moldovan, A.; Tetean, R.; Stiufiuc, R.; Lucaciu, C.M. Small versus Large Iron Oxide Magnetic Nanoparticles: Hyperthermia and Cell Uptake Properties. Molecules 2016, 21, 1357. [CrossRef] [PubMed]

45. Yen, H.J.; Young, Y.A.; Tsai, T.N.; Cheng, K.M.; Chen, X.A.; Chen, Y.C.; Chen, C.C.; Young, J.J.; Hong, P.D. Positively charged gold nanoparticles capped with folate quaternary chitosan: Synthesis, cytotoxicity, and uptake by cancer cells. Carbohydr. Polym. 2018, 183, 140-150. [CrossRef] [PubMed]

46. A Pankhurst, Q.; Connolly, J.; Jones, S.K.; Dobson, J. Applications of magnetic nanoparticles in biomedicine. J. Phys. D Appl. Phys. 2003, 36, R167-R181. [CrossRef]

(C) 2020 by the authors. Licensee MDPI, Basel, Switzerland. This article is an open access article distributed under the terms and conditions of the Creative Commons Attribution (CC BY) license (http://creativecommons.org/licenses/by/4.0/). 